\title{
Sometimes You Cannot Have It All: \\ Party Switching and Affiliation Motivations as Substitutes*
}

\author{
MARIUS RADEAN ${ }^{\dagger}$ \\ University of Essex
}

\begin{abstract}
Existing research on when legislators switch parties reports inconsistent results about motivations for switching (e.g., office, ideology, and votes). I treat the motivations for party switching as substitutes and argue that many of the inconsistencies that persist can be explained by modelling the interactive effects between these motivations. For example, scholars differ in terms of whether they find that electoral considerations are an important determinant of party switching. The conflicting findings on the independent effects of electoral considerations are explained here by demonstrating that these effects are conditional on the level of office benefits a legislators enjoys, as well as the ideological distance between the legislator and party. More generally, the empirical analysis provides strong support for the substitution effect hypothesis. Thus, modelling interactive effects increases our understanding of party switching.
\end{abstract}

\footnotetext{
*Note: I thank Matt Golder, Lawrence Ezrow, Christopher Reenock, David Siegel, and Jonathan Slapin for helpful comments on this paper. The data and all computer code necessary to replicate the results and figures in this analysis will be made publicly available on my homepage on publication.

${ }^{\dagger}$ Lecturer, Department of Government, University of Essex, Wivenhoe Park, Colchester, Essex, CO4 3SQ, United Kingdom, mradean@essex.ac.uk
} 


\section{Introduction}

By switching parties between elections, politicians alter the partisan and ideological composition of legislatures without voters' sanction. The deviation from the legislative party configuration produced by election results has important normative implications for democratic representation and accountability, since party defectors often end up pushing policies sought by their new party, not the voters who elected them (Desposato 2004, Nokken 2000). ${ }^{1}$ On a practical level, frequent party switching can break apart legislative coalitions and forge new majorities, which undermines the stability of democratic governments (Giannetti \& Benoit 2009, Giannetti \& Laver 2001). Such concerns with party switching have led many countries to adopt laws to regulate interparty movement. Currently, more than forty states have some type of law against parliamentary party defection (Janda 2009, Mershon 2012).

The effectiveness of anti-defection legislation is, of course, predicated on knowing what motivates legislators to engage in party switching. Arguably, the existing political science literature is not a reliable resource for people drafting such legislation. Theoretically, access to office benefits, ideological preferences, and electoral considerations should play an important role in explaining a legislator's decision to switch parties. Empirically, though, party switching studies have produced rather inconsistent results. For example, while some scholars find that legislators are more likely to switch to resource-rich parties (Desposato 2006, Desposato \& Scheiner 2008, McElroy 2009), others find that this is not the case (Heller \& Mershon 2005, Heller \& Mershon 2008, O’Brien \& Shomer 2013). Scholars also differ in terms of whether they find that the ideological distance between a legislator and his party is an important determinant of party switching (Desposato 2006, Desposato \& Scheiner 2008, Heller \& Mershon 2008, McElroy 2009). Similarly inconsistent results have been found with respect to the effect of electoral prospects on legislators' incentives to defect (Desposato \& Scheiner 2008, Heller \& Mershon 2005, Kato \& Yamamoto 2009, Reed \& Scheiner 2003, O’Brien \& Shomer 2013).

These conflicting findings come against the backdrop of a virtual consensus about the expected effect of party switching motivations. Specifically, the target party's resource wealth, its ability to facilitate the party defector's reelection, and the ideological congruence between the legislator and party, have been the-

\footnotetext{
${ }^{1}$ This is not to say that all party switching is opportunistic. In fact, depending on the assumption behind the type of mandate the representative enjoys as well as the reason for defection, it can be the case that party switching may improve representation (Heller \& Mershon 2009, 5).
} 
orized to positively affect the likelihood of party switching. Indeed, in spite of the fact that previous studies cover many countries, which exhibit a rich variety of institutional arrangements (Mershon 2014), there are no hypotheses which posit that these factors either do not affect, or decrease the likelihood of party switching. Therefore, from a theoretical perspective, cross-national variation in institutions alone cannot explain the divergent empirical results.

Because they go against generally accepted expectations, the divergent results have been classified as “surprising" (O'Brien \& Shomer 2013, 129) and "disappointing" (Heller \& Mershon 2005, 556). The fact that the empirical results are inconsistent is not only baffling, but it also carries problematic implications for existing theories. When empirical analyses report different results, the support for theoretical predictions translates to "patchy evidence" (Heller \& Mershon 2008, 918). ${ }^{2}$ I argue that these results are puzzling only through the lens of a theory which assumes that party switching determinants have similar effects in all scenarios, irrespective of the presence or absence of alternative party membership benefits. In this paper, I propose a theoretical account that relaxes this assumption and offers an explanation for why a given factor can have a strong effect in one case and a negligible effect in another. My theory posits that party membership benefits are substitutes, and, therefore, their net impact is contingent on the level of alternative benefits. Specifically, a party membership motivation plays a determinant role in explaining a legislator's decision to stay put or leave if it is the only benefit the party provides. However, it has only a minimal effect when party membership is associated with additional advantages.

In this paper, I test the substitution effect hypothesis using a dataset covering party switching in the $49^{\text {th }}$ and $50^{\text {th }}$ Brazilian legislatures from 1991 to 1999 (Desposato \& Scheiner 2008). I focus on Brazil because one can obtain indicators for the three main party switching determinants at the legislator-party dyad level. Having legislator-party level indicators allows for a more precise test of the theoretical implications, which assume that legislators see parties as distinct, meaningful alternatives. In particular, a distinctive feature of the Brazilian electoral system, i.e., open-list proportional representation (OLPR), allows one to assess a legislator's chances for electoral success across all party alternatives. In OLPR systems, the electorate can vote for a given party, or any of its candidates. The party label votes and the individual

\footnotetext{
${ }^{2}$ Based on in-depth knowledge of the data, Heller and Mershon (2008) provide alternative causal explanations for their againstexpectation results. The explanations are both sensible and plausible. Yet, because of the lack of variation on the alternative causal factors during the examined period, the implied causal mechanism is not tested (i.e., the respective factors are not included in the model estimation).
} 
candidates' votes are then pooled by party, and a formula determines how many seats each party gets. The seats are then awarded to the party's top candidates, who are ranked based on the number of personal votes received. For example, if a party wins three seats, they go to its top three candidates. On the one hand, because of the vote-pooling mechanism, the election of a marginal candidate is easier in a party where popular candidates bring in more individual votes than necessary to secure their own election. On the other hand, whether the candidate is assigned a seat depends on how they fare, in terms of personal votes received, relative to their fellow party members. In summary, depending on the other party members' performance, a candidate with a given number of personal votes can win a seat in one but not another party. ${ }^{3}$ The results of the empirical analysis provide strong support for the substitution effect hypothesis.

\section{Theory}

Although there are multiple reasons behind a legislator's decision to leave his home party, they generally can be subsumed under three board categories: office, ideology, and votes (Müller \& Strøm 1999). Officeseeking explanations emphasize the fact that politicians value legislative perks, which include things like cabinet portfolios and committee memberships. In order to maximize the level of private goods they enjoy, legislators prefer to be members of resource-rich parties (Desposato 2006, Desposato \& Scheiner 2008, McElroy 2009). Moreover, a party's access to state resources is a fungible asset that can translate, among other things, to electoral advantages. For example, by distributing public resources in areas or economic sectors that benefit their constituents, the incumbent can skew the playing field in their favor (Levitsky \& Way 2010, Stokes 2005). Therefore, given the important role that access to resources plays into legislators' calculation, the incentives to switch parties increase with the resource wealth of the target party.

The decision to switch parties is also influenced by legislators' ideological goals. Specifically, legislators who are driven by ideology prefer to affiliate with an ideologically close party that can help push their preferred policies. Conversely, being affiliated with people who hold contrasting views adversely affects a politician's ability to pursue their ideological agenda, and it can even make them vulnerable to sanctions. For example, to keep dissenting party members in line, party elites have to impose strict party discipline,

\footnotetext{
${ }^{3}$ In Online Appendix A, I provide more details about the seat allocation procedure under OLPR, as well as an example of how this works in practice.
} 
which in turn tends to alienate members (Heller \& Mershon 2005, Heller \& Mershon 2008). Thus, given that legislators also care about policy, they seek to affiliate with a party whose leadership and rank-and-file members have ideological goals similar to the legislator's own preferences.

One of the most common assumptions about politicians' motivations is that they are driven by the desire to gain and maintain office. In democracy, this often equates to winning elections. Not surprisingly, previous research has found a strong connection between electoral considerations and party switching. Specifically, legislators are more likely to switch at the beginning of the legislative term since voters tend to have short memories (Mershon \& Shvetsova 2008, Mershon \& Shvetsova 2013), and they prefer to affiliate with popular and up-and-coming parties to capitalize on the party's high approval ratings (Heller \& Mershon 2005, Kato \& Yamamoto 2009, O’Brien \& Shomer 2013, Reed \& Scheiner 2003). Likewise, legislators are more likely to switch in districts with low educated constituencies, where clientelism is more prevalent and politicians can secure electoral support with goods and services. In contrast, more educated constituents pay greater attention to policy outcomes and are, therefore, less understanding of politicians who switch parties and policy platforms (Desposato 2006, 73). Since winning elections is a necessary condition to enjoy any legislative benefits, switching to, or staying in, a party that can facilitate their reelection is a must for any ambitious legislator.

Do these motivations interact in determining whether a legislator switches parties? All existing theoretical accounts posit that party switching determinants are not connected, and, therefore, their effects do not intertwine. On the one hand, it is reasonable to assume that, for example, a party's status as a member of the government coalition is not linked to its ideological position since parties from both the left and right can be in the cabinet. On the other hand, party characteristics come as a package and legislators cannot cherry pick the cabinet status of one party, the ideological position of another one, and the electoral appeal of a third party. In effect, legislators choose among bundles of benefits, not individual party membership traits. Therefore, unless we assume that most party defectors severely misjudged their current party, such that there is no one single dimension in which the home party is the closest party with respect to the legislator's ideal position, then party switching entails a tradeoff. Affiliating with a different party might improve a legislator's utility on one dimension, but, most likely, it comes at the expense of a decrease in the level of another benefit. 
Thus, legislators are not able to selectively choose individual party traits. Furthermore, the characteristics of their party of choice can change suddenly. It is well documented that government coalitions form and break apart throughout the legislative session, so access to state resources tends to be temporary (Laver \& Shepsle 1996, Powell 2000). Similarly, political scandals of senior party figures can bring the demise of the entire party, and therefore they negatively affect the reelection prospects of all those associated with that party label (BBC News 2016, Desposato 2006). Even parties' ideological platform, which tends to be more stable, can change at times altering the level of ideological congruence between a party and its members. The Brazilian electoral law, for example, lists changes to a party's agenda as one of the three just causes for defection (Tribunal Superior Eleitoral 2007). Such external shocks reshuffle a party's characteristics, rendering a legislator's ability to simultaneously enjoy all party membership benefits a remote possibility, or, at best, a transient occurrence.

By presuming complete separation among the motivations of party switching, the literature implicitly assumes that party defectors can generally achieve the party affiliation trifecta; that is, membership in a party that i) has access to state resources, ii) is ideologically aligned with the legislator's position, and iii) can secure the legislator's reelection. Yet, only in special circumstances one can simultaneously maximize all these benefits, and, even then, only for a defined period. In contrast to the independent effects conjecture, this paper argues that party switching benefits are substitutes, which implies interactive effects. In practical terms, this means that high levels of a given benefit can compensate a legislator for the utility loss associated with the absence of another party membership advantage. Consequently, when a party can provide multiple benefits, the odds of any one motivation being decisive in determining whether a legislator defects are low. The reason for this is that resource rich parties can provide higher levels of a substitute benefit to counteract a sudden drop in the levels of an alternative advantage. In contrast, when the home party can provide only one benefit, that particular motivation plays a decisive role in explaining the legislator's decision.

Consider a stylized scenario where a politician is interested solely in office and ideological benefits. Following elections, the politician wins a seat as a member of the party that is ideologically the closest to his position. In the best case scenario, the legislator's party becomes a member of the government coalition, and the legislator enjoys high levels of both office and ideological benefits. In the alternative scenario, the legislator's party is left out of the government coalition. If the legislator decides to stay put, it must be the 
case that the high level of ideological congruence compensates for, presumably, low levels of office benefits. Alternatively, were the legislator to enjoy office benefits, he would have to switch to a party in power. Given the assumption of perfect ideological alignment between the legislator and his home party, a move to a party in power, and the resultant increase in the level of office benefits, would necessarily come at the cost of a decrease in ideological congruence. With respect to the relative effects of party switching motivations across these scenarios, the theory predicts that the impact of either determinant is smaller when both benefits are present. For example, a hypothetical increase in the ideological dissonance is posited to have a larger role in pushing an opposition legislator to switch, since a resource poor party cannot easily compensate the legislator for the utility loss. Thus, the effect of party switching motivations is contingent on the level of alternative benefits.

In summary, my theoretical account postulates that party switching benefits are substitutes, and its implications can be summed up in the following conditional hypothesis.

\section{The Conditional Nature of Party Switching Motivations' Effect Hypothesis:}

A legislator's incentives to switch parties increase with the level of any one party membership benefit associated with the target party (be it office, ideology, or votes). The positive effect of a given determinant is particularly large when the levels of the remaining benefits are low, but it diminishes as at least one of the other two benefits increases.

The proposition that office, ideology and votes are substitutes stands in contrast to two rival hypotheses. The first alternative hypothesis is that party switching motivations indeed interact in determining whether a legislator switches parties, but they are complements not substitutes. Were this the case, the effect of a party switching determinant would be heightened by the presence of another benefit. For example, a legislator's valuation of ideological congruence would increase with the resource wealth of the party, separate from the benefits directly associated with increased access to resources. The second competing hypothesis is that party benefits do not interact at all, and, therefore, they are neither substitutes nor complements. As noted above, this is the implied relation, or the lack thereof, among the party switching motivations in the current literature. Under the no interactive effects hypothesis, the effect of any given determinant should be constant across the levels of alternative benefits. For example, an increase in the ideological distance between a legislator's position and that of his party would have the same effect on the legislator's incentives regardless of whether the party is a member of the government coalition or of the opposition. 
Of course, which of the three competing hypotheses is supported by the data is an empirical question, and one that I address in the upcoming analysis.

\section{Empirical Analysis}

A proper test of the theoretical implications requires data at the legislator-party dyad level, since the theoretical account presupposes that legislators see parties as distinct alternatives. One limitation of this requirement is that we cannot conduct a cross-country analysis, since with this type of analysis one must employ aggregate-level data as a proxy for individual legislators' motivations (Mershon \& Shvetsova 2013, O’Brien \& Shomer 2013). Indeed, "without these party-level measures we cannot carry out a cross-national analysis of the determinants of party switching" (O'Brien \& Shomer 2013, Footnote 7, p. 134). On the one hand, cross-country studies generally enjoy higher levels of external validity. On the other hand, the use of aggregate-level indicators limits the type of questions one can address, and, in particular, it precludes a test of the hypothesis at hand.

Another limitation of the aforementioned requirement is that, in order to assess how a legislator's odds of reelection vary from party to party, only countries with specific electoral rules can be considered. For example, in closed-list PR electoral systems we cannot compute such an indicator since the electorate casts only a party vote, and individual candidate preferences are not recorded. Conversely, in pure SMD systems, the electorate casts only a candidate vote. Since only one candidate per party enters the electoral competition in each district, it is hard to disentangle voters' party from their candidate loyalties.

The challenges of identifying appropriate indicators for legislators' chances of electoral success are reflected, in part, by the heterogeneity in researchers' operationalization choices. To date, the standard approach has been to measure candidates' electoral prospects at either the individual or aggregate level. The individual-level measurements focus on the number of votes candidates receive in relation to the electoral threshold required to win a seat (Reed \& Scheiner 2003). The aggregate measurements capture either partyor systemic-level characteristics. At the party level, a defector's electoral prospects are affected by the party's candidate selection process as well as its electoral appeal (Kato \& Yamamoto 2009, O'Brien \& Shomer 2013). The systemic-level indicators focus on which electoral rules are best suited to insulate defectors from voter retribution (Heller \& Mershon 2005, O’Brien \& Shomer 2013). Both the individual- and aggregate- 
level indicators can lead to gross generalizations, though. For example, individual-level indicators assume that a candidate's chances of winning are constant across all parties. Were this the case, parties would not be a relevant actor in the electoral process. Conversely, party-level indicators assume that legislators associated with a particular party are equally likely to win. Of course, the chances of electoral success are not alike for all the candidates who share the same party label. Given the shortcomings of these types of measures, ideally, we want mid-level indicators, at the legislator-party dyad level.

As discussed above, Brazil is a fitting context to test the substitution effect hypothesis, since one can obtain indicators for the three main party switching determinants at the legislator-party level. In particular, Brazil's OLPR electoral system provides a great opportunity to measure a legislator's odds of reelection as a member of each available party. The reason for this is that the number of votes required for a candidate to win a seat varies across parties, in spite of the candidate securing the same number of personal votes. Another advantage of using Brazil is its candidato nato law, which was in effect during this period. The candidato nato law ensured that all incumbent legislators were automatically included on their party's electoral list (Desposato 2006, 70). The fact that during this period incumbents' nomination was not up for negotiation reduces the noise related to the exact terms of the negotiations over party switching, which typically occur in secret. Generally, the noise associated with the uncertainly over whether the legislator has secured the new host party's electoral support is relegated to the error term, which in turn decreases the model's efficiency.

\section{Data and Measurement Issues}

As noted earlier, I test my hypothesis on a dataset on party switching in the Brazilian Chamber of Deputies that covers the $49^{\text {th }}$ and $50^{\text {th }}$ legislatures (1991-1999). ${ }^{4}$ The data are organized into legislator-party dyads since we need to evaluate how the legislator's utility associated with membership in a given party varies across party alternatives. An example might help to illustrate the data structure. Suppose we have a single legislator, $L$, confronted with three legislative parties, $P_{A}, P_{B}$, and $P_{C}$. In this scenario, there would be three legislator-party dyads: $L-P_{A}, L-P_{B}$, and $L-P_{C}$. To capture the periodic realignment of the cabinet, I use cabinet spells as the affiliation opportunity period (Desposato \& Scheiner 2008). In effect, the legislators' affiliation choice is evaluated for each cabinet configuration. The main reason for this is that the

\footnotetext{
${ }^{4}$ The data and to a large extent the individual variables' description come directly from Desposato and Scheiner (2008).
} 
theory indicates that the resource wealth of parties is critical in determining whether a party switch occurs. Parties' access to state resources depends in turn on whether they are a member of the government coalition. Overall, in the dataset, there are 4,704 unique legislator choices, and 1,047 instances of party switching.

The dependent variable is Party Affiliation, which is coded one for the party with which the legislator affiliates in the current period, zero otherwise. An important and related control variable is Home Party, which captures the legislator's propensity to stay put in their current party. Home Party is coded one for the legislator's party at the beginning of the period, zero otherwise. When the legislator-party dyad indicated by Home Party differs from that indicated by Party Affiliation it means that a party switch has occurred. Apart from being instrumental in identifying party switching incidents, the Home Party variables captures, and implicitly controls for, all party-level characteristics not included in the model (e.g., party size), which set the home party apart from the other party alternatives (Desposato \& Scheiner 2008, 515).

According to the theoretical account, the interaction between three main factors plays a crucial role in determining whether a party switch occurs. These factors are the resource wealth of parties, their ability to facilitate their members' reelection, and the ideological preferences of both the party and legislator. With respect to the effect of parties' resource wealth, legislators are naturally drawn to parties that can offer high levels of office benefits. In line with previous studies of party switching, I use party membership in the president's coalition as a proxy for access to state resources. President's Coalition is coded one if the party is a member of the presidential coalition in a given time period, zero otherwise.

Given that politicians also care about policy, legislators prefer to be members of ideologically compatible parties. Thus, an increase in the ideological congruence between the legislator's ideological position and that of the target party should have a positive effect on the probability of party defection. Ideological Congruence is the reverse score of the absolute distance between the legislator's ideological position and that of the party. Higher values indicate that the legislator is ideologically close to the target party. Legislators' ideological position is estimated via the W-NOMINATE procedure, while a party's ideal position is calculated as the mean of all its members' ideological scores (Poole \& Rosenthal 1997).

The theoretical account also indicates that electoral prospects play an important role in determining a legislator's party choice. Reelection Prospects captures a legislator's chances for electoral success in a given party when accounting for the electoral strength of both the candidate and party list. It is coded 
one if the legislator would have been elected in that party, zero otherwise (Desposato 2006, Desposato \& Scheiner 2008). Of course, legislators are likely to affiliate with parties where election is easier.

Apart from the three party switching determinants on which I focus here, I also control for several additional factors that may influence legislators' decision. Since Brazil is a federal state, governors play an important role in the subnational politics, and they also have control over state-level resources. Having the support of the state governor at elections is extremely important in Brazil since the states are the electoral districts in which the candidates compete. Governor's Coalition is coded one if the party is a member of the governor's electoral coalition, zero otherwise.

As discussed above, being affiliated with the president's party is generally beneficial. However, it can have dire consequences when the president falls out of favor with the electorate. This was the case in 1992 when the sitting president was impeached for corruption. As a result, his party's popularity plummeted and reelection-seeking politicians had a strong incentive to avoid it. PRN captures the anti-PRN stigma associated with President Collor's party, and is coded one from the time the scandal broke until the end of that legislature, zero otherwise.

Besides the benefits they receive upon defection, politicians who are interested in party switching have to take into account any possible negative consequences as well. One source of transaction costs for legislators is voter scrutiny. The extent to which legislators are insulated from voter retribution, though, depends on demographic characteristics. Generally, legislators from less-developed areas, where clientelism is more prevalent, defect with impunity since they can secure electoral support with goods and services. Rural Electoral District captures the percentage of population leaving in rural areas in each of Brazil's twenty-seven states.

At the individual level, one personal characteristic that could affect a legislator's decision to switch is their previous legislative experience. The expectation is that senior, more experienced legislators are less likely to defect than junior deputies. The Number of Previous Terms variable captures the length of time the legislator has served in office. 


\section{The Empirical Model}

The theory posits that each party offers its members a bundle of benefits, and legislators choose the party alternative associated with the highest net benefit. One empirical strategy to evaluate the attractiveness of one alternative out of a larger choice set is the conditional logit model, CL (McFadden 1974, McFadden 1974a). In the CL model, the probability that legislator $i$ chooses party $j$ out of a set of $K$ legislative parties is

$$
\operatorname{Pr}\left(y_{i j}=1\right)=P_{i j}=\frac{e^{x_{i j} \beta}}{\sum_{k=1}^{K} e^{x_{i k} \beta}},
$$

where $\beta$ represents a vector of coefficients, and $x_{i j}$ represents a matrix of independent variables for legislator $i$ associated with party alternative $j$. The conditional probability accounts for the fact that each party alternative is not independent of all the others, and that each legislator can choose to affiliate with only one of the legislative parties.

This approach is appropriate in the party switching context because it accounts not only for the factors that push a legislator to leave his home party, but also for the specific bundle of benefits that the alternative parties can offer (Desposato 2006, Desposato \& Scheiner 2008, McElroy 2003, McElroy 2009). In fact, party switching presupposes that the legislator is unhappy in his current party and that there is another party that can offer a higher level of party membership benefits.

As is the case with all fixed effects models, the effects of choice-constant variables are conditioned out of the CL likelihood function unless they are interacted with a choice variable (Long 1997, Allison 2009). Therefore, I interact the Rural Electoral District and Number of Previous Terms covariates with a dichotomous choice variable, (1-Home Party), such that a positive coefficient on these variables indicates that a party switch is more likely (Desposato 2006, Desposato \& Scheiner 2008). In contrast to binary choice models, the effects of the individual-level characteristics that are partialed out of the fixed effects estimation (e.g., a legislator's party leadership or committee membership status) are implicitly controlled in the CL (Allison 2009, 36). Since their effects are not relegated to the error term, the CL model is less prone to omitted variable bias than the simple logit/probit.

Recall that the theoretical account indicates that party switching benefits are substitutes. This means that a party can compensate their members for a decrease in any one benefit by offering higher levels of 
another benefit. Interaction models are the standard approach to test substitution effects (Brambor, Clark \& Golder 2006, Berry, Golder \& Milton 2012). Theoretically, since any of the three main determinants can be a substitute for the remaining two, a three-way interaction model is appropriate here. Empirically, though, this approach might be problematic because, at margins, some of the combinations among the relevant factors are often not realized. For example, as discussed in the theory section, it is unlikely that legislators can simultaneously maximize all party membership benefits for a sustained period of time. This expectation is borne out by the data. There are relatively few observations, roughly $1.5 \%$ of the entire sample, that fall into the ideal case scenario for the legislator: the target party is a member of the presidential coalition, it can facilitate the legislator's reelection, and the level of ideological congruence between the legislator and party is relatively high (i.e., above the $75 \%$ percentile). Given the very low number of observations in this scenario, the estimates' corresponding standard errors are likely to be large, which can lead to a type II error (i.e., the failure to reject a false null hypothesis). Acknowledging this data limitation, in the results section I also present the estimates from a two-way interaction model, where the effect of each party switching benefit is conditioned on the other two benefits alternatively, not simultaneously.

\section{Results and Discussion}

The results of the empirical analysis are shown in Table 1. The second column presents the estimates from a two-way interaction model where the effect of each party switching determinant is alternatively conditioned on the other two factors. The results from a three-way interaction model, where the effect of each party switching determinant is simultaneously conditioned on both remaining factors, are shown in the third column.

Recall that the Conditional Nature of Party Switching Motivations' Effect hypothesis indicates that a legislator's incentives to switch parties increase with the level of any one party membership benefit (be it office, ideology, or votes) associated with the target party, but more so when the levels of the other two benefits are low. The estimates from both interaction models provide support for this. With respect to the individual effects of office, ideology and votes, I find, as predicted, that when the other two factors have no influence on legislators' incentives (i.e. when their value is exactly zero), a legislator is more likely to defect to a resource-rich party, a party that is ideologically close, and a party that can facilitate 
Table 1: The Determinants of Party Switching

\begin{tabular}{lcc}
\hline Regressor & $\begin{array}{c}\text { Two-way Interaction } \\
\text { Model }\end{array}$ & $\begin{array}{c}\text { Three-way Interaction } \\
\text { Model }\end{array}$ \\
\hline Choice-Specific Factors & & \\
President's Coalition & $2.91^{* * *}$ & $3.16^{* * * *}$ \\
& $(0.33)$ & $(0.49)$ \\
Ideological Congruence & $3.38^{* * *}$ & $3.49^{* * *}$ \\
Reelection Prospects & $(0.23)$ & $(0.28)$ \\
& $0.67^{* *}$ & $0.91^{*}$ \\
President's Coalition $\times$ Ideological Congruence & $(0.33)$ & $(0.47)$ \\
& $-1.19^{* * *}$ & $-1.39^{* * *}$ \\
President's Coalition $\times$ Reelection Prospects & $(0.25)$ & $(0.37)$ \\
& $-0.57^{* * *}$ & -1.03 \\
Ideological Congruence $\times$ Reelection Prospects & $(0.10)$ & $(0.66)$ \\
& -0.05 & -0.23 \\
President's Coalition $\times$ Ideological Congruence $\times$ & $(0.24)$ & $(0.35)$ \\
$\quad$ Reelection Prospects & - & 0.35 \\
Governor's Coalition & $0.32^{* * *}$ & $(0.50)$ \\
& $(0.06)$ & $0.32^{* * *}$ \\
Home Party & $3.44^{* * *}$ & $(0.06)$ \\
& $(0.10)$ & $3.44^{* * *}$ \\
PRN & $-3.17^{* * *}$ & $(0.10)$ \\
Choice-Constant Factors & $(0.22)$ & $-3.17^{* * *}$ \\
Rural Electoral District & & $(0.22)$ \\
Number of Previous Terms & $0.08^{* * *}$ & \\
Log Likelihood & $(0.03)$ & $0.08^{* *}$ \\
Number of Unique Legislator Choices & $-1.17^{* * *}$ & $(0.03)$ \\
\hline & $(0.22)$ & $-1.17^{* * *}$ \\
& -4863.06 & $(0.22)$ \\
& 4704 & -4862.81 \\
& & 4704 \\
\hline
\end{tabular}

Note: Data are for the $44^{\text {th }}$ and $50^{\text {th }}$ Brazilian legislatures from 1991 to 1999. All Choice-Constant Factors variables, which do not vary across the set of party alternatives, are interacted with (1-Home Party), such that a positive coefficient on these variables indicates that a party switch is more likely.

their reelection. Evidence for this line of reasoning comes from the positive and statistically significant coefficients on President's Coalition, Ideological Congruence, and Reelection Prospects, respectively, in both the two-way and three-way interaction models.

Of course, given our conditional hypothesis, we are also interested in whether this positive effect decreases at higher values of the modifying variables. In the two-way interaction model, all interaction coefficients have the expected negative sign, and, with one exception, are also statistically significant. The 
exception is the Ideological Congruence $\times$ Reelection Prospects coefficient, which, while still negative, fails to reach the conventional levels of statistical significance. Similarly, the interaction terms from the threeway interaction model have the expected negative sign, and the interaction terms that comprise Reelection Prospects, one again, fail to reach the conventional levels of statistical significance. This suggests that the effect of electoral considerations is not statically significant for the entire range of the modifying variables.

A more useful way to assess interaction effects than looking at coefficients' sign, is to graph the effect of the relevant factors across the modifying variables' range. When examining the covariates' conditional effects, there are two quantities of interest. First, we are interested in whether the predicted effect is statistically different from zero. Second, in order to evaluate the interaction hypothesis, we need to determine whether the predicted probabilities are also statistically different from one another. When quoting the average effect of a given factor, one usually reports the $95 \%$ confidence intervals around the mean to indicate whether that range includes the zero value. When assessing the difference between two means at the 5\% level, though, the $84 \%$ confidence intervals should be produced instead (Julious 2004). ${ }^{5}$ Since my conditional hypothesis requires a comparison between a determinant's effects at different values of the modifying variable(s), in the figures below, I report the $84 \%$ confidence intervals. While the reported level of the confidence intervals addresses the question of whether the predicted effects are statistically different from one another, the pattern of the confidence intervals indicates whether the estimated effect is statistically different from zero. Specifically, solid lines around a predicted effect indicate that the respective effect is statistically significant (e.g., Figure 1 Panel I.a and I.b), whereas dash lines indicate that the effect is not statistically different from zero at the $5 \%$ level (e.g., Figure 3 Panel I.b and II.b).

Using the estimates from the two-way interaction model, Figure 1 Panel I.a shows the effect of President's Coalition on the probability of party defection across the range of Ideological Congruence. All

\footnotetext{
${ }^{5}$ The rational for this has to do with the fact that the confidence interval for the difference between two means is not as wide as the confidence interval required to reject the null hypothesis that the lower and upper bounds of the respective means overlap. On the one hand, the confidence interval for the difference between two means is $\bar{x}_{A}-\bar{x}_{B} \pm Z_{1-\alpha / 2} s \sqrt{\frac{2}{n}}$, where $\bar{x} *$ is the expected mean, $Z$ is the standard score, $\alpha$ is a given level of statistical significance, $s$ is the standard error, and $n$ is the sample size. Therefore, there is a statistically significant difference between the means if $\frac{\sqrt{n}\left(\bar{x}_{A}-\bar{x}_{B}\right)}{\sqrt{2} s}>Z_{1-\alpha / 2}(1)$. On the other hand, there is no overlap between the lower and upper bounds of the respective means if $\bar{x}_{A}-Z_{1-\alpha / 2} s \sqrt{\frac{1}{n}}>\bar{x}_{B}+Z_{1-\alpha / 2} s \sqrt{\frac{1}{n}}$, which leads to $\frac{\sqrt{n}\left(\bar{x}_{A}-\bar{x}_{B}\right)}{\sqrt{2} s}>\sqrt{2} Z_{1-\alpha / 2}(2)$. It is easy to note that, for the same value of $\alpha$, the right-hand side would be roughly $\sqrt{2}$ times as big in Eq. (2) compared to (1). An $84 \%$ confidence interval around the individual means, instead of the $95 \%$, accounts for this difference, and it allows one to assess whether the two means are statistically different at the 5\% level or lower (Julious 2004 , 217-218)
} 
non-modifying variables are held at their means or, in the case of dichotomous variables, at their modes. As predicted, the effect of access to resources is larger when it is the only benefit that the target party offers (i.e., when Ideological Congruence is zero). The positive effect, though, diminishes as the legislator becomes ideologically closer to the target party. This suggests that ideological benefits mitigate the effect of access to resources on a legislator's incentive to defect. Figure 1 Panel I.b, which shows the effect of President's Coalition conditioned on whether the legislator is likely to be reelected as a member of that party, indicates that the appeal of a party in power is significantly lower when the party can also facilitate the defector's reelection. The reason for this is that when a party can offer defectors additional advantages, the positive effect of any one party switching determinant diminishes. Since the respective confidence intervals do not overlap, the predicted effects are statistically different at the 5\% level.

Figure 1 Panel II shows the effect of the target party's access to resources on the probability of party defection based on the estimates from the three-way interaction model. In this model, the effect of President's Coalition is simultaneously conditioned on both Ideological Congruence and Reelection Prospects. Yet, the substantive results are very similar to the ones from the two-way interaction model. Specifically, Figure 1 Panel II.a shows the effect of President's Coalition across the range of Ideological Congruence given that the legislator's reelection prospects in that party are low. It is easy to note that the positive effect of access to state resources declines sharply as the target party becomes ideologically closer to the potential party defector. Ideological proximity also mitigates the positive effect of access to resources on the legislator's incentive to switch to a party where his reelection prospects are high, a scenario presented in Figure 1 Panel II.b. Yet, in the latter case, both the predicted effect and decay rate are lower. This is explained by the fact that the substitution effect of a given motivation is weaker when combined with another benefit, in this case high reelection prospects.

To assess the effect of President's Coalition conditioned on Reelection Prospects at given values of Ideological Congruence, we have to compare the predicted effects reported in Figure 1 Panel II.a vs. Panel II.b. For example, when ideological congruence is at minimum, the probability of a legislator switching to a party in power that is also associated with low reelection prospects is $.46(.43, .49)$, Figure 1 Panel II.a. In contrast, the probability of choosing a similar party that is associated with high reelection prospects drops by half to $.24(.12, .36)$, Figure 1 Panel II.b. This is consistent with the theoretical expectation that the effect 
Figure 1: The Effect of President's Coalition on Party Affiliation

\section{Two-way Interaction Model}
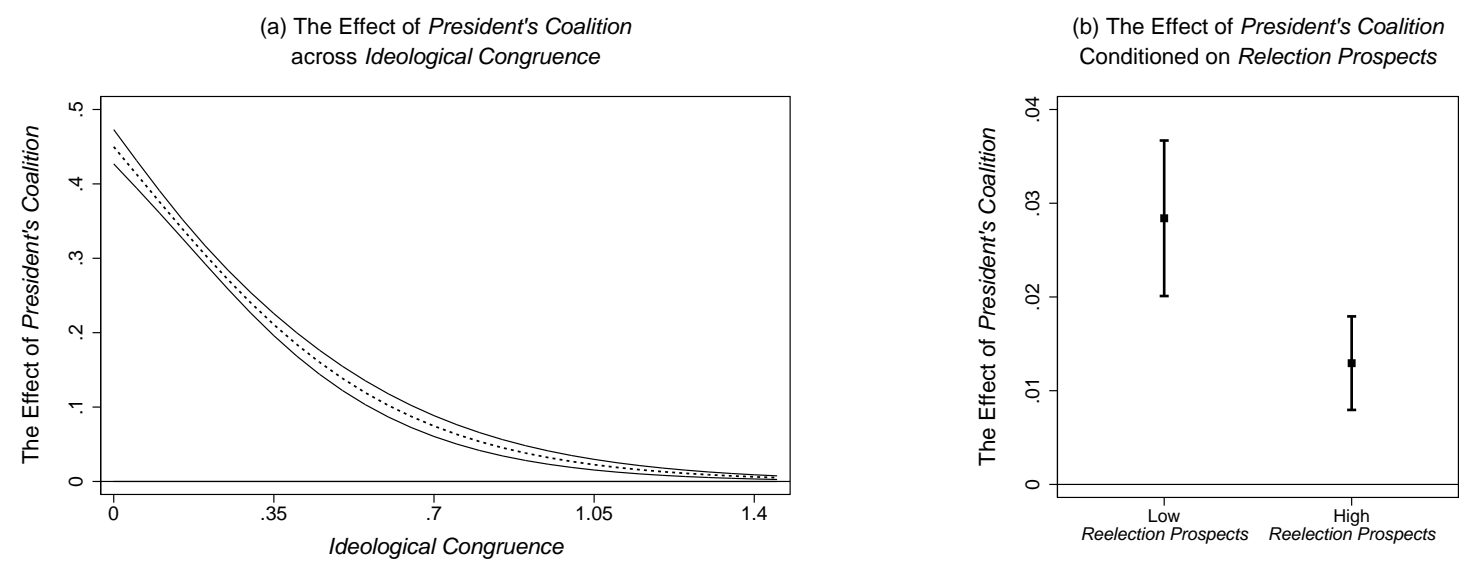

\section{Thee-way Interaction Model}

(a) Affiliating with a Party with Low Reelection Prospects

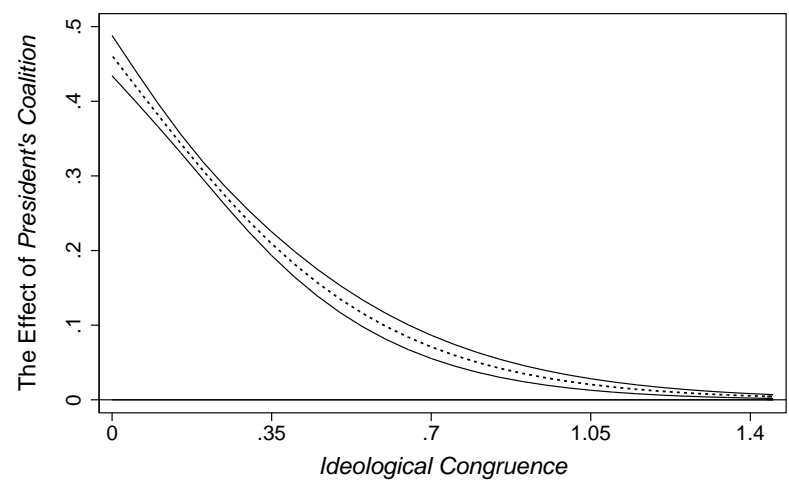

(b) Affiliating with a Party with High Reelection Prospects

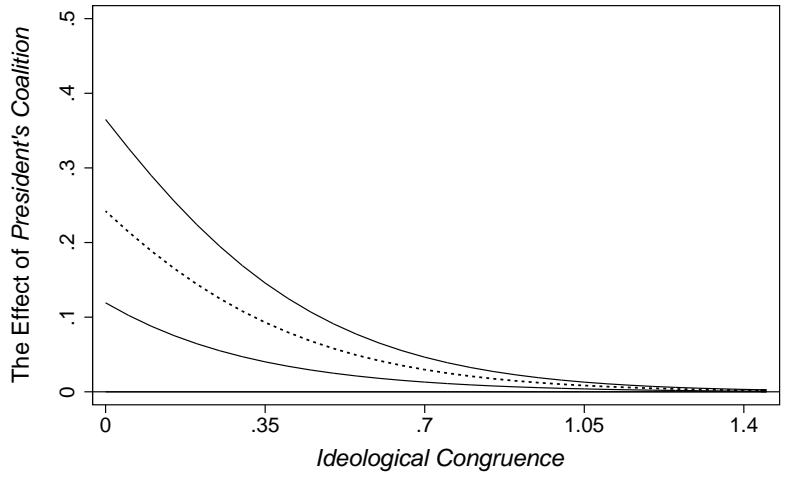

Note: Figure 1 illustrates the effect of President's Coalition on the probability of party affiliation conditioned on the level of Ideological Congruence and Reelection Prospects. The non-modifying variables are held at their means or, in the case of dichotomous variables, at their modes. The upper panel indicates the respective change in probability based on the estimates from the two-way interaction model, whereas the lower panel shows the difference in probabilities based on the three-way interaction model estimates. The predicted change in probability is indicated by a dotted line when the modifying variable is continuous, and by a solid square mark when the modifying variable is dichotomous. Solid lines for the confidence interval indicate that the predicted effect is statistically significant at the $5 \%$ level, whereas dash lines indicate that the respective effect is not statistically different from zero.

of a given party membership motivation is lower when the party can offer additional advantages. Since the confidence intervals do not overlap, it means that the two predicted effects are statistically different at the 5\% level. The effect of President's Coalition on the probability of party defection in statistically different between the low and high reelection prospects scenarios till about 1.05 on the Ideological Congruence scale.

Figure 2 Panel I.a and I.b shows the effect of increasing Ideological Congruence from its minimum to its maximum conditioned on whether the target party is a member of the presidential coalition, or it can 
Figure 2: The Effect of Ideological Congruence on Party Affiliation

\section{Two-way Interaction Model}
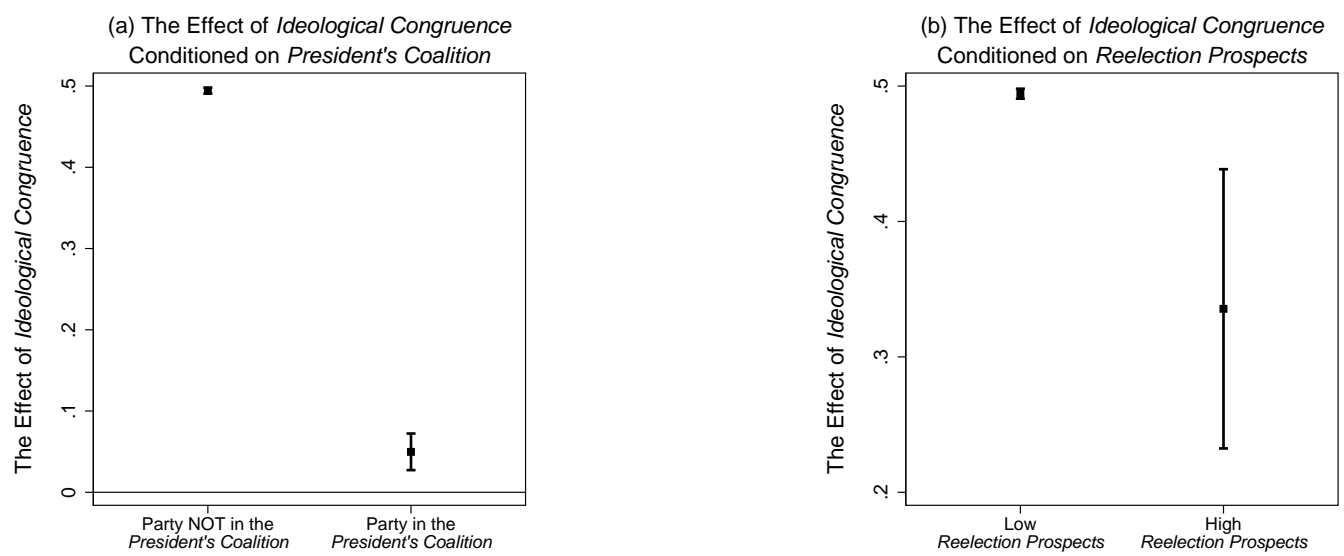

\section{Thee-way Interaction Model}

(a) The Effect of Ideological Congruence on the Probability of Party Affiliation

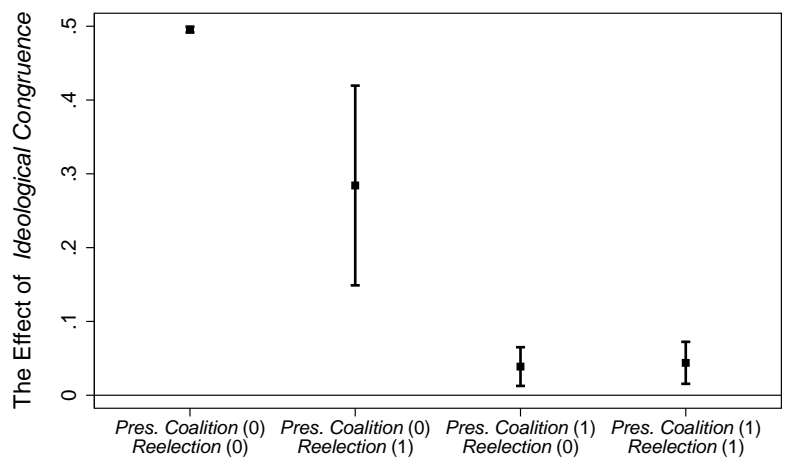

Note: Figure 2 illustrates the change in the probability of party affiliation when Ideological Congruence increases from its minimum to its maximum value conditioned on the level of President's Coalition and Reelection Prospects. The non-modifying variables are held at their means or, in the case of dichotomous variables, at their modes. The upper panel indicates the respective change in probability based on the estimates from the two-way interaction model, whereas the lower panel shows the difference in probabilities based on the three-way interaction model estimates. The predicted change in probability is indicated by a solid square mark. Solid lines for the confidence intervals indicate that the predicted effect is statistically significant at the 5\% level, whereas dash lines indicate that the respective effect is not statistically different from zero.

facilitate the legislator's reelection, respectively. These probabilities are computed employing the two-way interaction model estimates. As predicted, the positive effect of ideological proximity on party switching is higher when ideological benefits are the only perk the target party offers. Conversely, the effect of ideological congruence is significantly lower when the party can offer additional advantages, such as access to state resources, Panel I.a, or higher odds of reelection, Panel I.b. As indicated by the non-overlapping confidence intervals, the predicted effects are statistically different at the 5\% level. Figure 2 Panel II.a shows 
the effect of Ideological Congruence on the probability of party defection conditioned simultaneously on both President's Coalition and Reelection Prospects. Again, the substantive results from the two-way and three-way interaction models are quite similar. Specifically, the positive effect of ideological proximity is higher when it is the only benefit the target party can offer (i.e., when President's Coalition and Reelection Prospects are both zero). While still positive, the effect is significantly lower when membership in a given party is also associated with either office or electoral benefits, or both.

Figure 3 Panel I.a shows the effect of Reelection Prospects on the probability of party affiliation across the values of Ideological Congruence based on the two-way interaction model estimates. As predicted, the effect of electoral considerations is larger when the ideological congruence between the legislator's position and that of the party is at minimum, and the positive effect decreases as ideological proximity increases. Figure 3 Panel I.b shows the effect of Reelection Prospects conditional on whether the target party is a member of the presidential coalition. In line with the substitution effect hypothesis, the effect of electoral considerations is lower when the target party can offer additional advantages, in this case high levels of office benefits. Not only the predicted effect of electoral considerations is significantly lower when the party is a member of the president's coalition, but the effect is also statistically insignificant. This means that, at least in the Brazilian context, office benefits are a perfect substitute for electoral incentives.

Figure 3 Panel II shows the effect of Reelection Prospects on the probability of party affiliation conditioned simultaneously on both President's Coalition and Ideological Congruence. Figure 3 Panel II.a indicates that, when the target party is in the opposition, electoral considerations have a positive effect on the probability of party switching, but especially so at low levels of ideological congruence. Echoing the substitution effect result from the two-way interaction model, Figure 3 Panel II.b indicates that electoral considerations do not play a significant role in explaining a legislator's decision to switch to a resource-rich party, at any level of ideological congruence. The fact that in this scenario the predicted effect is statistically insignificant throughout the entire range of ideological proximity simplifies the task of assessing the effect of Reelection Prospects conditional on President's Coalition at given values of Ideological Congruence. Comparing the predicted effects reported in Figure 3 Panel II.a vs. Panel II.b, we can easily note that the confidence intervals virtually never overlap. This means that the effect of electoral prospects on the probability of party defection is statistically higher when the target party is in the opposition at all levels of 
Figure 3: The Effect of Reelection Prospects on Party Affiliation

\section{Two-way Interaction Model}

(a) The Effect of Reelection Prospects

across Ideological Congruence

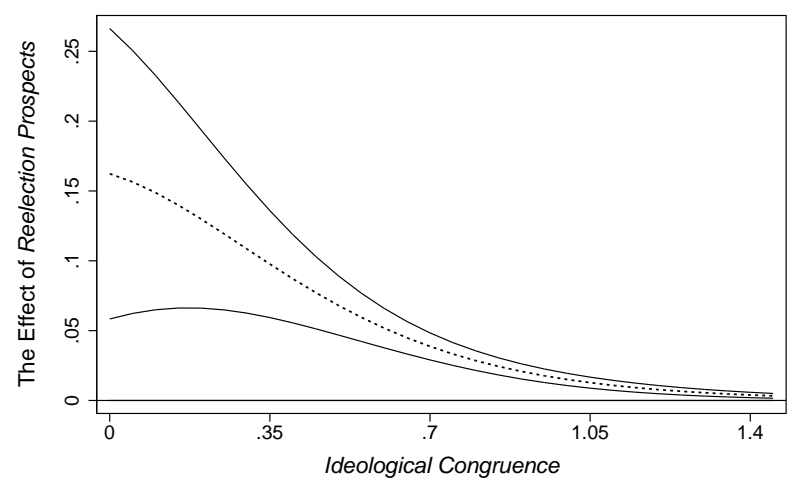

(b) The Effect of Reelection Prospects Conditioned on President's Coalition

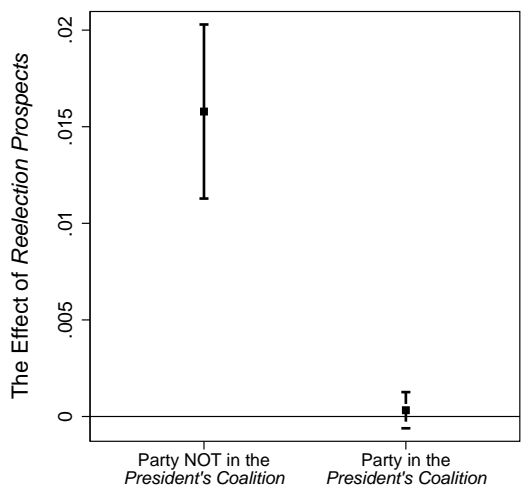

\section{Thee-way Interaction Model}

(a) Affiliating with a Party NOT in the President's Coalition

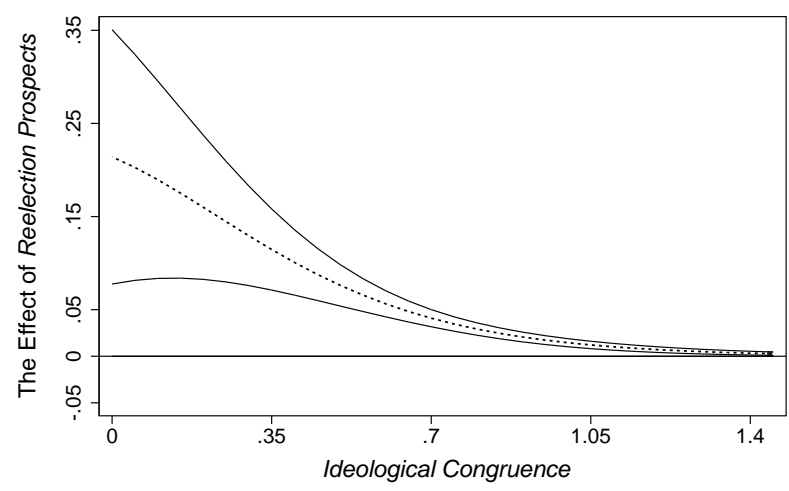

(b) Affiliating with a Party in the President's Coalition

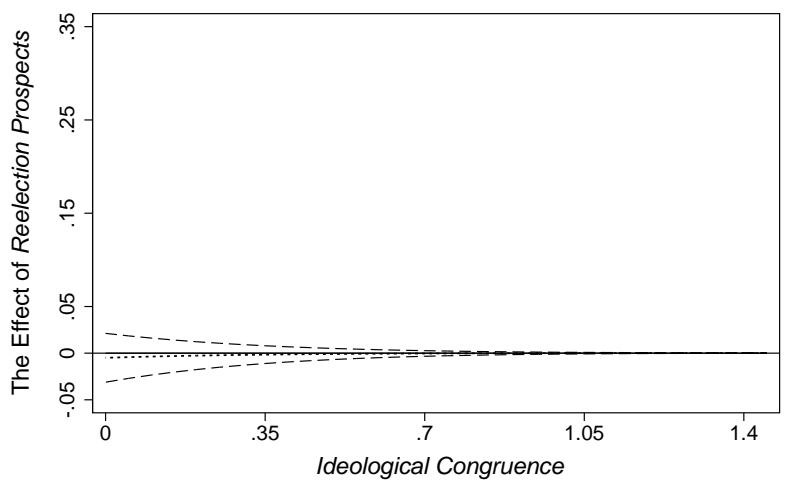

Note: Figure 3 illustrates the effect of Reelection Prospects on the probability of party affiliation conditioned on the level of Ideological Congruence and President's Coalition. The non-modifying variables are held at their means or, in the case of dichotomous variables, at their modes. The upper panel indicates the respective change in probability based on the estimates from the two-way interaction model, whereas the lower panel shows the difference in probabilities based on the three-way interaction model estimates. The predicted change in probability is indicated by a dotted line when the modifying variable is continuous, and by a solid square mark when the modifying variable is dichotomous. Solid lines for the confidence intervals indicate that the predicted effect is statistically significant at the 5\% level, whereas dash lines indicate that the respective effect is not statistically different from zero.

ideological congruence.

In summary, the results from both models provide strong support for the substitution effect hypothesis. Specifically, Figure 1, 2 and 3 show that the effects of access to resources, ideological preferences, and electoral considerations, respectively, are higher when the specific determinant is the only benefit the party provides. The positive effect, though, diminishes as the party is able to offer alternative, substitute benefits.

Last, in terms of the control variables, the results are in accord with those found in previous studies 
of party switching. Specifically, the positive and statistically significant coefficient on Home Party indicates that legislators are more likely to stay put in their current party. Also, legislators are more likely to switch to a party that has access to resources at the local level, and if they won their seat in a rural electoral district. Evidence for this line of reasoning comes from the positive and statistically significantly coefficients on Governor's Coalition and Rural Electoral District, respectively. Conversely, a legislator is less likely to switch to a party engulfed in a public scandal as indicated by the negative and statistically significant coefficient on $P R N$, the corruption-ridden party. Similarly, the negative and significant coefficient on Number of Previous Terms suggests that deputies with previous legislative experience are less likely to defect than their counterparts.

\section{Conclusion}

In recent years, concerns with party switching have led many countries to adopt laws to regulate parliamentary party defection. While party switching is a world-wide phenomenon with significant practical and normative implications, we have only a modest understanding of what motivates a legislator to defect. Theoretically, there is a broad agreement that office, ideology, and votes play an important role in explaining a legislator's decision to switch parties. Yet, the empirical results are, to a large extent, characterized by inconsistent findings. For example, scholars differ in terms of whether they find that office perks, ideological benefits, or electoral prospects are an important party switching determinant. None of the existing accounts, though, can theoretically explain why a given factor has a strong effect in one scenario and a negligible effect in another.

In this paper, I present a new theory that accommodates both sets of results. This paper argues that party switching benefits are substitutes, and, therefore, the net impact of a given motivation is contingent on the level of alternative benefits. The empirical analysis provides strong support for the substitution effect hypothesis. Specifically, the results indicate that office, ideology, and votes have the highest impact on the likelihood of party defection when the respective determinant is the sole party membership motivation. The positive effect, though, diminishes as the level of benefits associated with either one of the remaining two determinants, or both, increases. Indeed, the effect of a given party switching motivation differs at low and high levels of a substitute benefit. These results are robust to alternative model specifications where the 
effect of a given motivation is either alternatively (i.e, the two-way interaction model) or simultaneously (i.e, the three-way interaction model) conditioned on the remaining benefits.

Not only the effect of party switching motivations is not constant, but it may be negligible when the determinants are perfect substitutes. Case in point, in the Brazilian context, while generally significant, the effect of electoral considerations is negligible when the party has access to more resource wealth than other party alternatives. Similar null results have also been reported by previous studies that examine party switching in Japan and Italy (Desposato \& Scheiner 2008, Heller \& Mershon 2005). As is the case with all previous analyses, the two studies report only one (statistically insignificant) effect, whereas this analysis provides a more nuanced picture of the effect of electoral motivations. On the one hand, it acknowledges that when party defection is associated with high levels of office benefits, electoral considerations play only a trivial role, if any. On the other hand, it identifies alternative scenarios where electoral motivations play a substantial role, such as switching from a party in power to one in the opposition, or switching between opposition parties. In fact, consistent with my theoretical account, preliminary evidence seems to suggest that the null results from the Japan and Italy studies are due to a skewed distribution of the party switching incidents, such that a significant share involves opposition legislators switching to a party in power. ${ }^{6}$

Since previous studies of party switching do not model interactive effects, their estimates capture the average effect of party switching determinants across various levels of, and combinations between, alternative benefits. The average estimates, though, likely obscure the actual effect in any given scenario. In contrast, this study disentangles these effects and provides initial evidence of the tradeoff legislators face when deciding to switch. While the results of this first test of the causal mechanism are encouraging, the generalizability of results from single country analyses is typically limited. Yet, conducting a within country analysis is a necessary condition to test the hypothesis at hand, since this requires legislator-party dyad level indicators. To address the limited external validity issue, future studies should test the substitution effect hypothesis employing data from other countries, and, ideally, from alternative electoral systems. Another avenue for further research is to account for the motivations of the target party in a party switching trans-

\footnotetext{
${ }^{6}$ Specifically, in Japan, during the period studied there was no switching into the extant opposition parties (Desposato \& Scheiner 2008, 515). While Heller and Mershon (2005) do not report the exact ratio of opposition legislators switching to a party in power, we know from a different study conducted by the same authors that, in a previous legislative term, no legislator from the government coalition switched to an opposition party (Heller \& Mershon 2008, 920). If this pattern of party switching characterizes Italian politics generally, such that party switching commonly involves instances of opposition legislators switching to a government party, then that could explain the null results.
} 
action. While a couple of formal models recognize that party elites have a say in who is accepted into, or expelled from, their party (Desposato 2006, Laver \& Benoit 2003), none of the empirical analyses takes this into account. In effect, the literature assumes that legislators are automatically accepted into the party of their choice. 


\section{References}

Allison, Paul D. 2009. Fixed Effects Regression Models. Thousand Oaks, CA: SAGE Publications, Inc.

Ames, Barry. 2009. Interests, Identities, And Institutions In Comparative Politics: The Deadlock of Democracy in Brazil. Ann Arbor: The University of Michigan Press.

BBC News. 2016. "Brazil corruption: Is the government in crisis?" http://www.bbc.co.uk/news / world-latin-america-35810578 (Accessed: March 21, 2016).

Berry, William D., Matt Golder \& Daniel Milton. 2012. "Improving Tests of Theories Positing Interaction." Journal of Politics 74:653-671.

Brambor, Thomas, William Clark \& Matt Golder. 2006. "Understanding Interaction Models: Improving Empirical Analyses.” Political Analysis 14(1):63-82.

Desposato, Scott \& Ethan Scheiner. 2008. "Governmental Centralization and Party Affiliation: Legislator Strategies in Brazil and Japan.” American Political Science Review 102(4):509-524.

Desposato, Scott W. 2004. “The Impact of Party-Switching on Legislative Behavior in Brazil.” Working Paper. http: //pages.ucsd.edu/ sdesposato/ps2.pdf (Accessed: September 8, 2016).

Desposato, Scott W. 2006. "Parties for Rent? Careerism, Ideology, and Party Switching in Brazil's Chamber of Deputies." American Journal of Political Science 50(1):62-80.

Giannetti, Daniela \& Kenneth Benoit. 2009. Intra-Party Politics and Coalition Governments. New York, NY: Routledge.

Giannetti, Daniela \& Michael Laver. 2001. "Party System Dynamics and the Making and Breaking of the Italian Governments.” Electoral Studies 20:529-553.

Heller, William B. \& Carol Mershon. 2005. "Party Switching in the Italian Chamber of Deputies, 19962001.” The Journal of Politics 67:536-559.

Heller, William B. \& Carol Mershon. 2008. "Dealing in Discipline: Party Switching and Legislative Voting in the Italian Chamber of Deputies, 1988-2000.” American Journal of Political Science 52:910-925.

Heller, William B. \& Carol Mershon. 2009. Political Parties and Legislative Party Switching. New York, NY: Palgrave Macmillan.

Janda, Kenneth. 2009. "Laws Against Party Switching, Defecting, or Floor-Crossing in National Parliaments." Paper prepared for delivery at the 2009 World Congress of the International Political Science. Santiago, Chile July 12-16, 2009. http: //www.partylaw.leidenuniv.nl/uploads / wp020 9.pdf (Accessed: July 14, 2015).

Julious, Steven A. 2004. "Using Confidence Intervals Around Individual Means to Assesss Statistical Significance Between Two Means.” Pharmaceutical Statistics 3:217-222.

Kato, Junko \& Kentaro Yamamoto. 2009. Competition for Power: Party Switching and Party System Change in Japan. In Political Parties and Legislative Party Switching, ed. William B. Heller \& Carol Mershon. New York, NY: Palgrave Macmillan pp. 233-263. 
Laver, Michael \& Kenneth A. Shepsle. 1996. Making and Breaking Governments: Cabinets and Legislatures in Parliamentary Democracies. New York: Cambridge University Press.

Laver, Michael \& Kenneth Benoit. 2003. "The Evolution of Party Systems between Elections." American Journal of Political Science 47:215-233.

Levitsky, Steven \& Lucan A. Way. 2010. Competitive Authoritarianism: Hybrid Regimes after the Cold War. Cambridge University Press.

Long, J. Scott. 1997. Regression Models for Categorical and Limited Dependent Variables. Thousand Oaks, CA: SAGE Publications, Inc.

McElroy, Gail. 2003. "Party Switching in the European Parliament: Why bother?" Paper Prepared for Presentation at the 2003 Meeting of the European Consortium for Political Research, Marburg, Germany.

McElroy, Gail. 2009. Intra-Party Politics at The Trans-National Level: Party Switching in the European Parliament. In Intra-Party Politics and Coalition Governments, ed. Daniela Giannetti \& Kenneth Benoit. New York, NY: Routledge pp. 205-225.

McFadden, Daniel. 1974. Conditional Logit Analysis of Qualitative Choice Behaviour. In Frontiers in Econometrics, ed. P. Zarembka. New York: Academic Press pp. 105-42.

McFadden, Daniel. 1974a. "The Measurement of Urban Travel Demand.” Journal of Public Economics 3:303-328.

Mershon, Carol. 2012. "Curbing Elite Discretion: Enforcement of Constraints on Legislative Party Switching." Paper presented at the 2012 Annual Meeting of the Midwest Political Science Association, Chicago IL.

Mershon, Carol. 2014. Legislative Party Switching. In The Oxford Handbook of Legislative Studies, ed. Shane Martin, Thomas Saalfeld \& Kaare W. Strøm. Oxford, U.K.: Oxford University Press pp. 418435 .

Mershon, Carol \& Olga Shvetsova. 2008. "Parliamentary Cycles and Party Switching in Legislatures." Comparative Political Studies 41:99-127.

Mershon, Carol \& Olga Shvetsova. 2013. Party System Change in Legislatures Worldwide. New York, NY: Cambridge University Press.

Müller, Wolfgang \& Kaare Strøm. 1999. Policy, Office, or Votes? How Political Parties in Western Europe Make Hard Decisions. Cambridge: Cambridge University Press.

Nokken, Timothy P. 2000. "Dynamics of Congressional Loyalty: Party Defection and Roll-Call Behavior, 1947-97.” Legislative Studies Quarterly 25(3):417-444.

O’Brien, Diana Z. \& Yael Shomer. 2013. "Legislators' Motivations, Institutional Arrangements, and Changes in Partisan Affiliation: A Cross-National Analysis of Party Switching." Legislative Studies Quarterly 38(1):111-141.

Poole, Keith \& Howard Rosenthal. 1997. Congress: A Political-Economic History of Roll Call Voting. New York: Oxford University Press. 
Powell, G. Bingham. 2000. Elections as Instruments of Democracy. New Haven: Yale University Press.

Reed, Steven R. \& Ethan Scheiner. 2003. "Electoral Incentives and Policy Preferences: Mixed Motives Behind Party Defection in Japan.” British Journal of Political Science 33:469-490.

Stokes, Susan C. 2005. "Perverse Accountability: A Formal Model of Machine Politics with Evidence from Argentina." American Political Science Review 99(3):315-25.

Tribunal Superior Eleitoral. 2007. "Fidelidade partidária." Resoluçâo-TSE $n^{o}$ 22.610/2007 October 25, 2007. http: / / www.tse.jus.br/partidos/fidelidade-partidaria (Accessed: January 6, 2016). 


\section{Online Appendix A: An OLPR Hypothetical Election Example}

In the main text, I note that Brazil employs an open list proportional electoral system (OLPR), which uses the D'Hondt formula for seat allocation. In what follows, I present an example that illustrates the seat allocation procedure under OPLR. On election day, the electorate may vote for an individual candidate or the party label. In Brazil, “[m]ost people-about 90 percent-vote for an individual” (Ames 2009, 42). Under the OLPR electoral rules, a candidate's odds of electoral success are affected by the number of personal votes received as well as his party's overall vote share. Take for example a hypothetical electoral district with 160 voters and 4 open seats. For these seats compete 8 candidates $\left(c_{n}\right.$, where $\left.n \in\{1,2, \ldots, 8\}\right)$ who are affiliated with either Party $A$ or Party $B$. The results from two alternative elections, which differ only in terms of whether candidate $c_{3}$ is a member of Party $A$ or $B$, are shown in Table 2. In both scenarios, all candidates and parties enjoy the same level of electoral support. In particular, candidate $c_{3}$ receives the same number of personal votes regardless of his party affiliation, which indicates that his supporters would follow him across party lines.

Table 2.a shows the vote distribution across all candidates and parties. For example, in the first scenario, candidate $c_{2}$ receives 25 personal votes, Party $A$ receives 10 party label votes and has a grand total of 100 votes. A party's total number of votes is the sum of the votes received by all its candidates plus the party label votes. Table 2.b shows how the seats are allocated to parties, which is a function of parties' overall vote share. The four seats are allocated to the party/parties with the four largest quotients, according to the D'Hondt formula. The formula is $\frac{V}{s+1}$, where $V$ is a party's total number of votes, and $s$ is the number of seats that the party has been allocated so far (initially 0 for all parties), such that $\max (s+1)$ is the total number of open seats.

How many seats does each party win, and which candidates are assigned a seat? In the first scenario, adding the 6 votes cast for $c_{3}$, Party $A$ has 100 votes, whereas Party $B$ has only 60. Dividing the parties' votes by the respective divisors (i.e., 1, 2, 3, and 4), we obtain the quotients presented in Table 2.b, First Scenario. The four largest quotients are identified by an adjacent *. It is easy to see that, in this scenario, Party $A$ wins three seats, and Party $B$ only one. As a result, the top three candidates from Party $A$ (in terms of the number of personal voters received), and the top candidate from Party $B$ win a seat. In Table 2.a, First Scenario, the four winning candidates are identified by an adjacent *. Note that, as a member of Party $A$, 
Table 2: The Seat Allocation Procedure under OLPR with D'Hondt Formula

Table 2.a: The Vote Tally and the Seat Winners

\begin{tabular}{lcc}
\hline $\begin{array}{l}\text { Parties and } \\
\text { Candidates }\end{array}$ & First Scenario & Second Scenario \\
\hline Party $A$ & & \\
$\mathrm{c}_{1}$ & $58^{*}$ & $58^{*}$ \\
$\mathrm{c}_{2}$ & $25^{*}$ & $25^{*}$ \\
$\mathrm{c}_{3}$ & $6^{*}$ & - \\
$\mathrm{c}_{4}$ & 1 & 1 \\
Party Label Votes & 10 & 10 \\
Total Votes & 100 & 94 \\
Party $B$ & & \\
$\mathrm{c}_{5}$ & $30^{*}$ & $30^{*}$ \\
$\mathrm{c}_{6}$ & 14 & $14^{*}$ \\
$\mathrm{c}_{7}$ & 8 & 8 \\
$\mathrm{c}_{3}$ & - & 6 \\
$\mathrm{c}_{8}$ & 2 & 2 \\
Party Label Votes & 6 & 6 \\
Total Votes & 60 & 66 \\
\hline
\end{tabular}

Table 2.b: The Seat Allocation Procedure

\begin{tabular}{|c|c|c|c|c|c|c|}
\hline & \multicolumn{5}{|c|}{ D'Hondt Quotients } & \multirow{3}{*}{ Seats Won $(*)$} \\
\hline & \multirow{2}{*}{$\frac{\text { Nominator }(V)}{\text { Total Votes }}$} & \multicolumn{4}{|c|}{ Denominator $(s+1)$} & \\
\hline & & 1 & 2 & 3 & 4 & \\
\hline \multicolumn{7}{|c|}{ First Scenario } \\
\hline Party A & 100 & $100^{*}$ & $50 *$ & $33.33^{*}$ & 25 & 3 \\
\hline Party B & 60 & $60^{*}$ & 30 & 20 & 15 & 1 \\
\hline \multicolumn{7}{|c|}{ Second Scenario } \\
\hline Party A & 94 & $94^{*}$ & $47^{*}$ & 31.33 & 23.5 & 2 \\
\hline Party B & 66 & $66^{*}$ & $33^{*}$ & 22 & 16.5 & 2 \\
\hline
\end{tabular}

Note: The D'Hondt formula for the quotient is: $\frac{V}{s+1}$, where $V$ is a party's total number of votes, and $s$ is the number of seats that the party has been allocated so far; initially 0 for all parties. The four winning candidates in Table 2.a as well as the four largest party quotients in Table 2 .b are identified by an adjacent *

candidate $c_{3}$ is assigned a seat while Party $B$ 's candidates $c_{6}$ and $c_{7}$ fail to win a seat in spite of both having more personal votes than $c_{3}$.

In the second scenario, candidate $c_{3}$ is a member of Party $B$, and, therefore, their 6 personal votes count towards Party $B$ 's total number of votes. As a result of the extra votes, Party $B$ now wins two seats 
instead of one (see Table 2.b, Second Scenario). Yet, as indicated by the Table 2.a, Second Scenario results, the extra seat goes to candidate $c_{6}$ not $c_{3}$. In fact $c_{3}$ is not even the runner-up candidate, as $c_{7}$ has more personal votes as well. In practical term, this means that candidate $c_{3}$ would win a seat in Party $A$, but not in Party $B$. 